\title{
Evolution of enhanced reproduction in the hybrid-derived invasive, California wild radish (Raphanus sativus)
}

\author{
Caroline E. Ridley • Norman C. Ellstrand
}

Received: 18 November 2007 / Accepted: 5 December 2008/Published online: 25 December 2008

(C) The Author(s) 2008. This article is published with open access at Springerlink.com

\begin{abstract}
Evolution is receiving increased attention as a potentially important factor in invasions. For example, hybridization may have stimulated the evolution of invasiveness in several well-known plant pests. However, the mechanism for success of such hybrid-derived lineages remains unknown in the majority of the cases studied. Here we ask whether increased reproductive success (in terms of maternal fitness) has evolved in an invasive lineage with confirmed hybrid ancestry. We compare the relative fitness of the non-native, hybrid-derived California wild radish (Raphanus sativus) to that of its two progenitor species in field experiments at different sites and in different years. We found that California wild radish has high survivorship and produces more fruits per plant and more seeds per plant than either of its progenitors in several environments. Furthermore, populations of California wild radish display a strong
\end{abstract}

C. E. Ridley · N. C. Ellstrand

Department of Botany and Plant Sciences, University

of California, Riverside, CA 92521, USA

N. C. Ellstrand

Center for Conservation Biology, University

of California, Riverside, CA 92521, USA

C. E. Ridley $(\square)$

Department of Ecology, Evolution and Behavior, University of Minnesota, St. Paul, MN 55108, USA

e-mail: ridle026@umn.edu genotype-by-environment interaction, indicating that maintenance of genetic and phenotypic diversity between populations may be responsible for the weed's ability to invade a wide breadth of California habitats. Our results suggest that hybridization may contribute the evolution of enhanced invasiveness and, also, that by limiting the introduction and subsequent hybridization of congeners, we may be able to prevent the evolution of new invasive lineages.

Keywords Common garden experiment . Fitness traits - Genotype $\times$ environment interaction . Hybridization · Invasiveness $\cdot$ Raphanus

\section{Introduction}

Evidence is mounting that evolution can be an important factor in the invasion process (Barrett et al. 2008; Cox 2004; Dlugosch and Parker 2008; Keller and Taylor 2008; Lambrinos 2004; Lee 2002). Evolutionary change can be rapid and substantial in introduced populations, in some cases stimulating the creation of novel, highly invasive genotypes (Dlugosch and Parker 2008; Ellstrand and Schierenbeck 2006).

Hybridization, defined as the successful mating of two genetically distinct sources (e.g., Arnold 1997), could be quite common in populations of non-native, sexually reproducing species because introductions 
often originate from multiple and/or geographically diverse source populations (e.g., Bartlett et al. 2002; Durka et al. 2005; Genton et al. 2005; Maron et al. 2004; Marrs et al. 2008; Novak and Mack 2001). Such intraspecific hybridization has been implicated in enhancing invasiveness in several species, including both plants and animals (Facon et al. 2005; Lavergne and Molofsky 2007). Many well-known examples of interspecific hybrid invaders also exist. Spartina anglica in Britain is derived from the hybridization of an introduced species, S. alterniflora, with the native $S$. maritima, while the hybrid lineage between introduced $S$. alterniflora and the native $S$. foliosa is invading the West Coast of North America (Ainouche et al. 2004; Ayres et al. 2003).

Although several coincidences of hybridization with invasion have been identified (Ellstrand and Schierenbeck 2006), the mechanisms by which hybrid-derived lineages establish and spread have been rarely studied. The simplest explanation might be that hybridization creates genotypes that are more reproductively successful than the pure progenitor genotypes, perhaps as a result of fixed heterosis, the purging of deleterious alleles or the transfer of adaptations (Ellstrand and Schierenbeck 2006; Rieseberg et al. 1999). All other things being equal, a lineage that reproduces more is likely to be more invasive because of the prime importance of propagule pressure during the invasion process (Colautti et al. 2006; Hayes and Barry 2008; Lockwood et al. 2005). Increased genetic diversity relative to progenitor populations might also affect the success of hybrid-derived populations by enhancing their ability to respond to selection and to adaptively evolve (Ellstrand and Schierenbeck 2006; Lee 2002; Parker et al. 2003; Sakai et al. 2001). However, hybridderived lineages do not necessarily have to display a reproductive advantage to be more invasive than their introduced progenitors (Bergelson 1994). In theory, they could show one of the other qualities of a good invader, such as superior competitive or dispersal ability. Our system, the California wild radish (Raphanus sativus), is an extensively studied nonnative lineage that is appropriate for examining the mechanism $(s)$ of hybrid invasive success.

In the mid-1800s, two Raphanus species colonized the San Francisco Bay area of California. Cultivated radish $R$. sativus was introduced intentionally as a crop. Raphanus raphanistrum, also known as jointed charlock, arrived accidentally, probably as a weed contaminant of grain (Panetsos and Baker 1967; Robbins 1940). Native to the Mediterranean, $R$. raphanistrum has been listed as one of the world's worst weeds (Holm et al. 1997) and is an agricultural pest in Canada, the northern United States and Australia (Snow and Campbell 2005). Both R. sativus and $R$. raphanistrum are annual and self-incompatible. The two species are differentiated by a number of genetically-based traits including root morphology, fruit morphology, flower color and flowering time (Hegde et al. 2006; Panetsos and Baker 1967). They also differ from one another by a single chromosomal reciprocal translocation that results in partial reproductive isolation via $50 \%$ reduced fertility in the $F_{1}$ generation (Panetsos and Baker 1967). This reproductive barrier is easily overcome, however, such that later generation hybrids have substantially recovered fertility (Snow and Campbell 2005).

As late as the 1960 s, both morphologically pure populations of each introduced Raphanus species and clearly hybrid-derived populations were not uncommon in coastal and inland northern California (Panetsos and Baker 1967). Some 40 years later, in a wide sampling of Raphanus throughout the state, hybrid genetic ancestry was found for every population (Hegde et al. 2006; Ridley et al. 2008). Thus, over the last century, the two Raphanus species have coalesced into a hybrid lineage that has displaced all natural populations of both parents. Commonly referred to as "California wild radish", this lineage is now found throughout a major portion of naturally disturbed coastal areas and human-disturbed inland sites in California (DiTomaso and Healy 2006; Panetsos and Baker 1967), as well as south into Baja California, Mexico and north into Oregon (Hegde et al. 2006; Ridley 2008). Interestingly, interspecific Raphanus hybrids also appear in Europe, but are not invasive (Stace 1975).

Raphanus is an important model system. Plant ecologists, evolutionists and geneticists have all used Raphanus for studying pollination biology, lifehistory variation, ecological genetics, floral evolution and plant-herbivore interactions (e.g., Campbell et al. 2006; Conner 1997; Elam et al. 2007; Ellstrand et al. 1989; Irwin et al. 2003; Marshall and Diggle 2001; Mazer and Schick 1991; Stanton et al. 1991).

Here, we use a common garden field experiment to gain evidence for one mechanism by which 
California wild radish has replaced its progenitors on the western coast of North America. Phenotypically, California wild radish tends to show intermediacy to its progenitor species for many traits, including bolting and flowering dates, and root length and width, but it exceeds both progenitors for average fruit weight, a potential fitness correlate (Hegde et al. 2006). In addition, advanced generation artificial $R$. sativus $\times R$. raphanistrum hybrids grown in southern California have shown a significant survival and reproductive advantage over the weedy progenitor, $R$. raphanistrum (Campbell et al. 2006). Given this evidence, we hypothesize that the naturally hybridderived California wild radish will show enhanced fitness relative to the species that hybridized to create it, and that this could be one mechanism for its successful establishment and spread in the state.

\section{Methods}

Plant material

Sources of California (CA) wild radish, $R$. raphanistrum and cultivated radish used in this study are listed in Table 1. In 1998, we conducted a statewide collection of CA wild radish. We chose five populations for this study that represent both the geographic range of wild radish in California and its morphological range varying from appearing crop-like to $R$. raphanistrum-like. Several sources of $R$. raphanistrum were likewise chosen to represent the species' geographic range, including sites from which plants could have been introduced to California. Seeds from native habitat in Europe (Denmark) and two naturalized populations from North America (Mexico and Rhode Island) were included. The $R$. raphanistrum populations chosen had no evidence of prior introgression from the crop. Cultivars are likely ancestors of the current CA wild radish populations based on molecular analysis (Ellstrand and Marshall 1985; Ridley et al. 2008).

To obtain sufficient seed for multiple years of field studies, seed was multiplied from the original CA wild radish and $R$. raphanistrum populations two times: once in 2004 for a 2005 common garden and again in 2005 for two common gardens planted in 2006. In each year, one seedling from 10 to 12 different maternal families per population was germinated and grown in a $12 \mathrm{~cm}^{3}$ pot of sterilized UC Soil Mix III (Matkin and Chandler 1967) inside an insect-excluded, temperature-controlled greenhouse on the campus of the UC Riverside. Once all individuals of a population reached flowering, they were crossed within each population. This approach has the benefit of eliminating possible maternal environmental effects of field-collected seed. In summer 2004, when local populations of wild radish were no longer flowering, populations were taken out of the greenhouse one by one and exposed to natural pollinators for up to 7 days. Pollinated plants were taken back into greenhouse isolation for at least
Table 1 List of source populations used in the experiment

\begin{tabular}{|c|c|c|}
\hline Species & Population/Cultivar & Source location \\
\hline \multirow[t]{3}{*}{ R. raphanistrum } & Denmark & $\begin{array}{l}\text { Roskilde University Botanic } \\
\text { Garden }\end{array}$ \\
\hline & Mexico & Mexico City \\
\hline & Rhode Island & Conanicut Island \\
\hline \multirow[t]{5}{*}{ CA wild } & San Mateo County, northern coastal & Half Moon Bay State Beach \\
\hline & Tulare County, central inland & Lindcove \\
\hline & $\begin{array}{l}\text { San Luis Obispo County, } \\
\text { central coastal }\end{array}$ & Morro Bay State Park \\
\hline & Riverside County, southern inland I & Riverside \\
\hline & Riverside County, southern inland II & Hemet \\
\hline \multirow[t]{4}{*}{ Cultivated } & Cherry Belle, round red & Ferry-Morse Seed Co. \\
\hline & French Breakfast, long pink & Ferry-Morse Seed Co. \\
\hline & Round Black Spanish & Botanical Interests, Inc. \\
\hline & White Icicle, long white & Botanical Interests, Inc. \\
\hline
\end{tabular}


one month until fruits were mature for harvesting. In winter 2005, seeds were germinated and grown as in 2004 and then hand-crossed in the greenhouse. Two dehiscing anthers were plucked from each of three flowers on all individuals within a population and placed in a $1.5 \mathrm{ml}$ microcentrifuge tube. A small paintbrush was then dipped into the mixed pollen load, and pollen was applied to 2-5 flowers per branch on 2-3 branches per plant. The paintbrush was cleaned with ethanol before pollen application to the next plant. Fruits were allowed to mature on the plants under the same greenhouse conditions. In 2004, crosses within one CA wild radish population (San Mateo County) failed and, therefore, this population was not included in 2005 of the common garden experiment.

\section{Common garden design}

Year 1 of the experiment was planted on March 7, 2005 at UC Riverside's Agricultural Experiment Station in Riverside, CA, USA. Fifty seeds from each greenhouse-multiplied source (except San Mateo County) and 50 from each cultivar source were planted in a randomized complete block design, 550 individuals total. This site experiences extreme temperatures, with nearly 100 days per year over $32^{\circ} \mathrm{C}$, and typically receives little rainfall during the growing season, 34.0 and $136.4 \mathrm{~mm}$ of total precipitation in 2005 and 2006, respectively, during the months of the experiment. Year 2 was planted at the same Riverside site on January 23, 2006 and at UC's South Coast Research and Extension Center in Irvine, CA on January 30-31, 2006. The common garden design from 2005 was replicated at both locations, except that 50 San Mateo County individuals were added at each site. The Irvine location has a contrasting climate to that in Riverside, with more moderate temperatures (fewer than 40 days per year over $32^{\circ} \mathrm{C}$ ) and with higher relative rainfall. During the experiment in 2006 , the site received a total of $189.9 \mathrm{~mm}$ of precipitation.

For both field seasons and sites, seeds were germinated in the greenhouse at UC Riverside in flats of sterilized UC Soil Mix III (Matkin and Chandler 1967). Seedlings were watered daily with fertilized water (100 ppm 21-5-20 Peters EXCEL). At the one-leaf stage, seedlings were transplanted and watered into the field in 10 complete, randomized blocks of 55 individuals each in 2005 and 60 individuals each in 2006. In 2005, the Riverside site received $90 \mathrm{~min}$ of overhead irrigation per week from March 31 to May 2 in weeks with no precipitation. In 2006, the Riverside site received 30 min of overhead irrigation per day from January 23-27 and 30 min per week from February 3-23 in weeks with no precipitation. The Irvine site received $60 \mathrm{~min}$ of overhead irrigation per week from February 3-24. The field sites were hand-weeded and treated for heavy insect infestations on several occasions (Riverside 2005: March 9, Ortho Bug-B-Gon, 0.0033\% esfenvalerate and March 21, Crymax Bt, 20 g/2.5 gal; Irvine 2006: March 2, Serin 80s, 80\% carbaryl, 1 lb/acre). On June 16-22, 2005 and June 4-8 (Riverside) and June 24July 16, 2006 (Irvine), after all plants had senesced, aboveground biomass was collected and stored.

\section{Phenotypic measurements}

Fitness traits and some phenotypic traits that may directly or indirectly impact fitness were measured on all experimental plants in 2005. In 2006, phenotypic traits were measured on all plants, and fitness traits were measured on a subsample of plants large enough to statistically detect a $30 \%$ difference in seed output between species at an $\alpha$-level of 0.05 with $95 \%$ confidence, as determined by power analysis (Sokal and Rohlf 1995). Traits that were measured during the field season included days to flowering, length of longest leaf at flowering $(\mathrm{cm})$ and root crown diameter at flowering $(\mathrm{mm})$. Days to flowering was calculated as number of days from germination in the greenhouse to the date of the first flower opening. At the end of the experiment, three female fitness traits were measured including number of fruits per plant, average number of seeds per fruit and overall seeds per plant. We measured number of fruits by counting enlarged pedicles (which indicate successful pollination and fruit formation) on dried plants and estimated average number of seeds per fruit by opening and visually assessing viable seed number for 10 separate fruits from each plant. Seed number was estimated by multiplying number of fruits by average number of seeds per fruit for each individual. The three fitness traits we measured were used previously to estimate fitness in Raphanus (Campbell et al. 2006; Snow et al. 2001). We did not attempt to measure male fitness in this experiment. We do, 
however, note that a prior study showed a significant, but biologically weak, relationship between male and female fitness in CA wild radish (Devlin and Ellstrand 1990).

Data analysis

For the purposes of our data analysis, we are treating cultivated radish, $R$. raphanistrum, and CA wild radish as three different "species" types. For each species in each site-year, we tabulated the number of individuals in four categories: (a) died, (b) survived to the end of the experiment but did not flower, (c) flowered but produced no seed and (d) flowered and produced seed. We tested for differences between species in their distribution across categories, combining site-years, using a likelihood ratio chi-square test using JMP 7.0 (SAS Institute Inc 2007).

Each continuous reproduction variable was statistically analyzed using a mixed model analysis of variance (ANOVA) where species, population within species, site and year were fixed effects and block, higher order interactions and error were random effects (SAS Institute Inc 2003). Number of fruits and number of seeds were natural $\log$ and natural $\log$ (+1) transformed, respectively, to meet the assumptions of normality. When an ANOVA factor was found to explain a significant amount of variance after a sequential Bonferroni correction (Rice 1990), planned mean contrasts were calculated to test for specific differences between species within site-years. Only individuals that survived to produce at least one fruit were included in the ANOVAs for fitness traits.

As it became clear that significant population within species $\times$ year and population within species $\times$ site interactions were present, we used a simplified relative distances plasticity index $\left(\mathrm{RDPI}_{\mathrm{s}}\right)$ to compare the phenotypic plasticity in reproduction between populations of the two fittest taxa: $R$. raphanistrum and CA wild radish. $\mathrm{RDPI}_{\mathrm{S}}$ is the distance between mean trait values, in our case seed output, in all pairs of environments calculated for each population (Valladares et al. 2006). We used a simple two-sample $t$-test assuming unequal variances to find significant differences in plasticity between species.

We also analyzed total relative fitness using a multiplicative fitness function. For each site-year, we multiplied viability by the average fecundity of the three different species and normalized the product to the highest fitness in each site-year. We then applied a Fisher exact tests to compare the cumulative fitness of California wild radish relative to cultivated radish and $R$. raphanistrum separately (Nason and Ellstrand 1995). We repeated the test for all three site-years.

\section{Results}

Survival, flowering and setting seed

Rates of survival for both CA wild radish and $R$. raphanistrum were high across years and sites (Fig. 1). California wild radish consistently flowered and set seed at rates of $95 \%$ and above, regardless of year or site. Raphanus raphanistrum flowered and set seed at a rate of $100 \%$ at Irvine in 2006, and somewhat less in Riverside in both 2005 and 2006. Cultivated radish had the lowest survival rate, rate of flowering, and rate of setting seed in all site-years. Chi-square analysis revealed a highly significant difference between species in their distribution across life stage categories $(N=1,009, d f=6, P<0.0001)$. When cultivated radish was removed from the analysis, a highly significant difference still remained between CA wild radish and $R$. raphanistrum, with $96 \%$ of CA wild radish individuals flowering and setting seed overall versus $81 \%$ of $R$. raphanistrum individuals $(N=654, d f=3, P<0.0001)$.

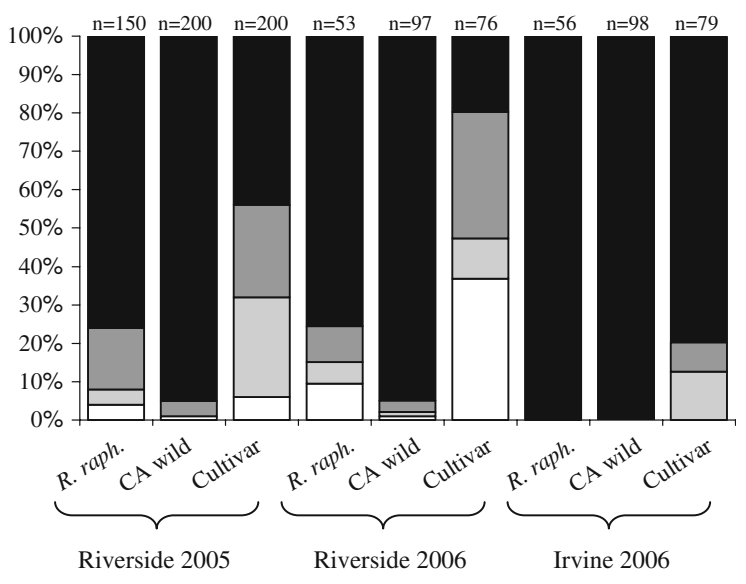

Fig. 1 Percentage of individuals in each species and each siteyear within the following life stage categories by the end of the experiment, shown with samples sizes: a Died (white), b Survived to end of experiment, but never flowered (light gray), c Flowered but produced no seeds (dark gray) and d Flowered and produced seeds (black) 
Table 2 Phenotypic measurements for each species in all site-years
Numbers represent means and $95 \%$ confidence intervals

\begin{tabular}{lllll}
\hline Field site & Species & $\begin{array}{l}\text { Days to } \\
\text { flowering }\end{array}$ & $\begin{array}{l}\text { Length of longest } \\
\text { leaf at flowering }(\mathrm{cm})\end{array}$ & $\begin{array}{l}\text { Root crown diameter } \\
\text { at flowering }(\mathrm{mm})\end{array}$ \\
\hline Riverside 2005 & R. raphanistrum & 45.6 & 12.2 & 5.4 \\
& $n=137$ & $(43.0-48.2)$ & $(11.1-13.3)$ & $(4.8-6.0)$ \\
& CA wild & 45.8 & 17.7 & 9.6 \\
& $n=196$ & $(43.9-47.7)$ & $(16.1-19.3)$ & $(8.2-11.0)$ \\
& Cultivated & 90.9 & 22.0 & 52.4 \\
& $n=136$ & $(87.6-93.3)$ & $(20.3-23.7)$ & $(48.5-56.3)$ \\
Riverside 2006 & $R$. raphanistrum & 70.5 & 17.2 & 6.9 \\
& $n=136$ & $(67.9-73.1)$ & $(15.6-18.8)$ & $(6.2-7.7)$ \\
& CA wild & 80.9 & 20.8 & 12.9 \\
& $n=242$ & $(78.2-83.6)$ & $(19.3-22.3)$ & $(11.4-14.4)$ \\
& Cultivated & 115.3 & 21.8 & 42.9 \\
& $n=111$ & $(113.6-117.0)$ & $(19.9-23.8)$ & $(38.6-47.2)$ \\
Irvine 2006 & R. raphanistrum & 68.0 & 23.7 & 9.4 \\
& $n=149$ & $(65.6-70.4)$ & $(21.6-25.8)$ & $(8.4-10.4)$ \\
CA wild & 74.4 & 28.8 & 18.8 \\
$n=247$ & $(71.7-77.1)$ & $(26.7-30.9)$ & $(16.8-20.8)$ \\
& Cultivated & 117.2 & 21.4 & 47.0 \\
$n=171$ & $(115.8-118.6)$ & $(19.2-23.6)$ & $(43.6-50.4)$ \\
\hline & & &
\end{tabular}

Traits measured at first flowering

For most traits measured in most site-years, CA wild radish displayed an intermediate phenotype to its progenitor parents, trending towards greater similarity to $R$. raphanistrum (Table 2). At Riverside in 2005, flowering was simultaneous for CA wild radish and $R$. raphanistrum, both significantly earlier than the cultivars. In another exception to intermediacy, in Irvine 2006, CA wild radish had longer leaf length at flowering than both parent species. Additionally, plants generally tended to flower more quickly and at a smaller size in Riverside 2005 compared to both field sites in 2006, though cultivars maintained a similar size at flowering across siteyears.

Fruit and seed production

Across years at Riverside, there was a significant difference in seed production between species, as well as a significant difference between populations within species (Table 3). There was, however, no significant effect of year itself. Significant interaction effects between both species and year and population within species and year indicate a genotype $\times$ environment interaction at the species and population levels. Because of these significant interaction effects, we continued analyzing each year separately.

Table 3 ANOVA results testing the effect of year and site on the number of seeds produced per plant

\begin{tabular}{|c|c|c|c|}
\hline $\begin{array}{l}\text { Site-years } \\
\text { compared }\end{array}$ & Effect & $d f$ & $F$ value \\
\hline \multirow{6}{*}{$\begin{array}{l}\text { Riverside } 2005 \text { and } \\
\text { Riverside } 2006 \\
(n=557)\end{array}$} & Year & 1 & 0.03 \\
\hline & Species & 2 & $4.28 *$ \\
\hline & $\begin{array}{l}\text { Population within } \\
\text { species }\end{array}$ & 9 & $9.83 * * *$ \\
\hline & Block within year & 12 & 0.72 \\
\hline & Year $\times$ Species & 2 & $6.69 * *$ \\
\hline & $\begin{array}{l}\text { Year } \times \text { Population } \\
\text { within species }\end{array}$ & 7 & $4.66^{* * *}$ \\
\hline \multirow{6}{*}{$\begin{array}{l}\text { Riverside } 2006 \text { and } \\
\text { Irvine } 2006 \\
(n=366)\end{array}$} & Site & 1 & $76.67 * * *$ \\
\hline & Species & 2 & $5.72 *$ \\
\hline & $\begin{array}{l}\text { Population within } \\
\text { species }\end{array}$ & 9 & $9.44 * * *$ \\
\hline & Block within site & 6 & 0.58 \\
\hline & Site $\times$ Species & 2 & 2.75 \\
\hline & $\begin{array}{c}\text { Site } \times \text { Population } \\
\text { within species }\end{array}$ & 8 & $3.85^{* *}$ \\
\hline
\end{tabular}

$* P<0.05, * * P<0.001, * * * P<0.0001$ 
Within the second year, 2006, individuals at Irvine produced an average of almost twice as many seeds as individuals at Riverside, and this effect of site was highly significant (Table 3 ). There was also a significant impact of both species and population within species on total seed production per plant. A marginally significant interaction between species and site and a significant interaction between population within species and site indicated a genotype $\times$ environment interaction and led us, as with year, to analyze sites separately.

At Riverside in 2005, species had a significant effect on fruit production, but not on number of seeds per fruit or overall seed production (Table 4). Nevertheless, CA wild radish out-reproduced both $R$. raphanistrum and cultivars by $\sim 300 \%$ in terms of fruits per plant and seeds per plant (Fig. 2a, c). Significant variation was also present between populations within a species. Within CA wild radish, San Luis Obispo County and Riverside County I had relatively high reproductive output compared to Tulare County and Riverside County II (Fig. 3b). Raphanus raphanistrum from Mexico and Denmark reproduced more than individuals from Rhode Island (Fig. 3a) and cultivars Black Spanish and White Icicle out-reproduced Cherry Belle and French Breakfast (Fig. 3c).

In 2006 at Riverside, a different picture emerges. Species did not account for a significant amount of variation in the three measurements of maternal fitness, but population within species did (Table 4). Raphanus raphanistrum individuals nearly tripled average seed production from 2005 to 2006, driven by an increase in fruit production (Fig. 2a, c). Simultaneously, fruit production and seed production declined in CA wild radish, eliminating any statistical difference between it and $R$. raphanistrum. While $R$. raphanistrum increased relative fitness, cultivated individuals experienced decreased fitness in 2006 compared to 2005 (Fig. 2).

Table 4 ANOVA results for all maternal fitness traits measured in the experiment

\begin{tabular}{|c|c|c|c|c|c|}
\hline Field site & Effect & $d f$ & $\begin{array}{l}\text { Ln (fruit number) } \\
n=410\end{array}$ & $\begin{array}{l}\text { Seeds per fruit } \\
n=411\end{array}$ & $\begin{array}{l}\text { Ln }(\text { seed number }+1) \\
n=410\end{array}$ \\
\hline \multirow[t]{5}{*}{ Riverside 2005} & Species & 2 & $7.70 *$ & 2.55 & 4.52 \\
\hline & Population within species & 8 & $15.86^{* * *}$ & $7.19 * * *$ & $15.00 * * *$ \\
\hline & Block & 9 & 1.11 & 0.44 & 0.76 \\
\hline & Block $\times$ Species & 18 & 1.31 & 0.44 & 0.96 \\
\hline & Block $\times$ Population within species & 68 & 0.77 & 0.81 & 0.79 \\
\hline Field site & Effect & $d f$ & $\begin{array}{l}\text { Ln (fruit number) } \\
n=146\end{array}$ & $\begin{array}{l}\text { Seeds per fruit } \\
n=153\end{array}$ & $\begin{array}{l}\text { Ln (seed number }+1) \\
n=147\end{array}$ \\
\hline \multirow[t]{5}{*}{ Riverside 2006} & Species & 2 & 3.08 & 0.65 & 4.01 \\
\hline & Population within species & 8 & $2.68 * *$ & $6.61 * *$ & $3.38 * *$ \\
\hline & Block & 3 & 0.09 & $4.64 *$ & 0.14 \\
\hline & Block $\times$ Species & 6 & 0.43 & 1.12 & 0.83 \\
\hline & Block $\times$ Population within species & 20 & 0.67 & 0.94 & 0.47 \\
\hline Field site & Effect & $d f$ & $\begin{array}{l}\text { Ln (fruit number) } \\
n=222\end{array}$ & $\begin{array}{l}\text { Seeds per fruit } \\
n=219\end{array}$ & $\begin{array}{l}\text { Ln (seed number }+1) \\
n=219\end{array}$ \\
\hline \multirow[t]{5}{*}{ Irvine 2006} & Species & 2 & $7.26^{*}$ & 1.28 & $6.30 *$ \\
\hline & Population within species & 9 & $8.84 * * *$ & $5.54 * * *$ & $11.25 * * *$ \\
\hline & Block & 3 & 1.87 & 1.27 & 1.30 \\
\hline & Block $\times$ Species & 6 & 0.63 & 1.56 & 0.72 \\
\hline & Block $\times$ Population within species & 27 & 1.15 & 0.84 & 1.12 \\
\hline
\end{tabular}

Separate ANOVA's were conducted for each site-year due to significant Species $\times$ Year and Species $\times$ Site interaction effects. Numbers presented are $F$ values

$* P<0.05, * * P<0.01$, *** $P<0.001$ using sequential Bonferroni correction (Rice 1990) 

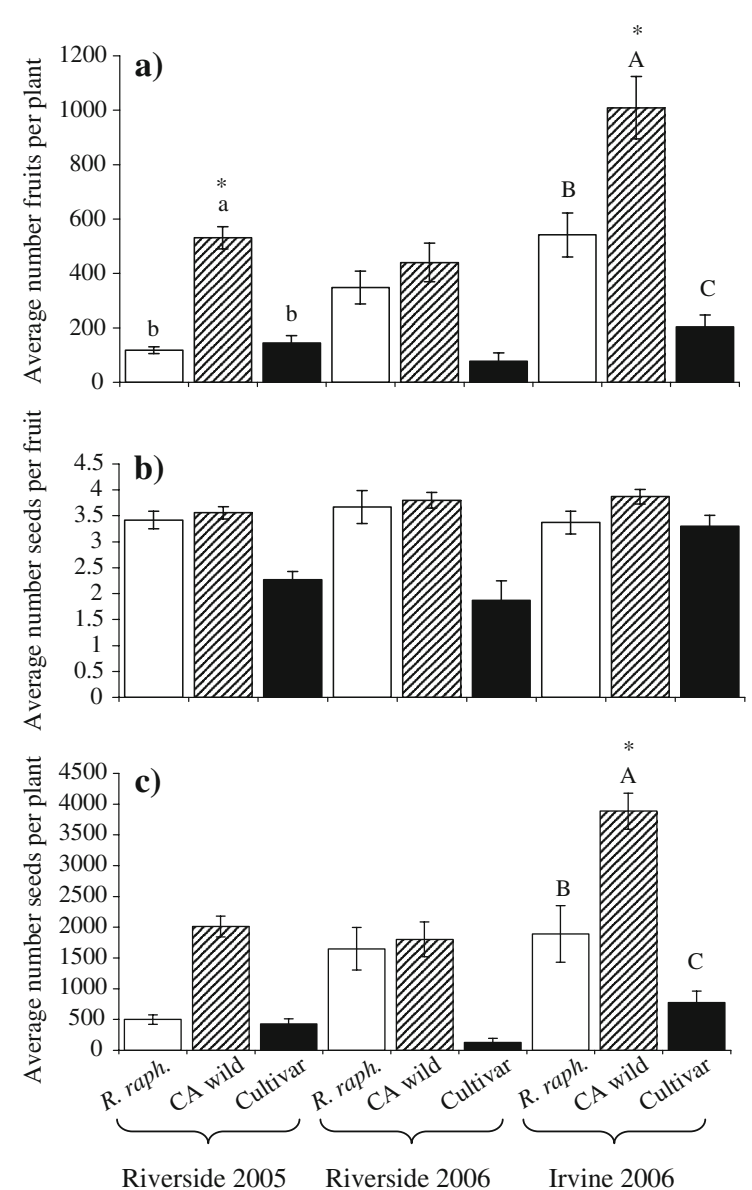

Fig. 2 Individual average a number of fruits per plant, $\mathbf{b}$ number of seeds per fruit and $\mathbf{c}$ number of seeds per plant for each species in each site-year \pm 1 SE. Asterisk indicates a significant effect of species on the trait within the site-year at the $P<0.05$ level using a sequential Bonferroni correction. Independent contrasts are also shown, where different letters indicate a significant difference in mean values at the $P<0.05$ level. Statistics were based on $\ln$ (fruits), seeds per fruit and $\ln$ (seeds +1 ), but untransformed values are presented for simplicity

As the significant year $\times$ population interaction suggested in the initial ANOVA, the rank of populations with respect to reproduction changed from year to year, in particular for CA wild radish. Whereas the San Luis Obispo County and Riverside County I populations reproduced the most in 2005, Riverside County II individuals produced the most seeds per plant in Riverside in 2006 (Fig. 3b). Rank order of parental populations and cultivars remain similar to that of 2005 (Fig. 3a, c).

At Irvine in 2006, CA wild radish produced $\sim 200$ and $500 \%$ more fruits than $R$. raphanistrum and cultivars, respectively (Fig. 2a), and this species effect was significant (Table 4). California wild radish also produced significantly more seeds per plant than either progenitor parent (Fig. 2c). Population within species continued to have a significant effect on all three female fitness traits (Table 4).

Rank of CA wild radish population reproduction changed between field sites, just as it changed between years. In Riverside in 2006, the worst reproducing population was from San Mateo County, but in Irvine in 2006, this population performed the best, showing more than a tenfold difference in seed production (Fig. 3b). Riverside County II, San Luis Obispo County and Tulare County individuals all reproduced more in Irvine, while Riverside County I individuals produced approximately the same number of seeds per plant as in Riverside. Mirroring the trend between years, the between site rank order of parental $R$. raphanistrum populations and cultivars was unchanged (Fig. 3a, c).

The statistical comparison of $\mathrm{RDPI}_{\mathrm{s}}$ between $R$. raphanistrum and CA wild radish was consistent with qualitative observations about genotype $\times$ environment interactions: CA wild radish had significantly higher plasticity than $R$. raphanistrum for seed output across all environments (Two sample $t$-test: $d f=20$, $P=0.02)$.

\section{Cumulative fitness}

Using a multiplicative fitness function, we found that California wild radish had a significant fitness advantage over both progenitor species in all siteyears (Table 5). Even in Riverside 2006 when survival and reproduction were similar between California wild radish and $R$. raphanistrum, the cumulative fitness of California wild radish exceeded that of its progenitor by $20 \%$.

\section{Discussion}

In this study, we demonstrate that a hybrid-derived, invasive lineage of plants can have a higher rate of survival to reproduction, higher reproductive output and higher overall cumulative fitness than its genetically pure progenitors. At the Riverside field site in both years, hybrid-derived California wild radish displayed enhanced survival relative to its 
Fig. 3 Individual average lifetime maternal reproductive output $\pm 1 \mathrm{SE}$ for each population of a $R$. raphanistrum, b California wild radish and $\mathbf{c}$ cultivars. Note that each graph is on a different $y$-axis scale

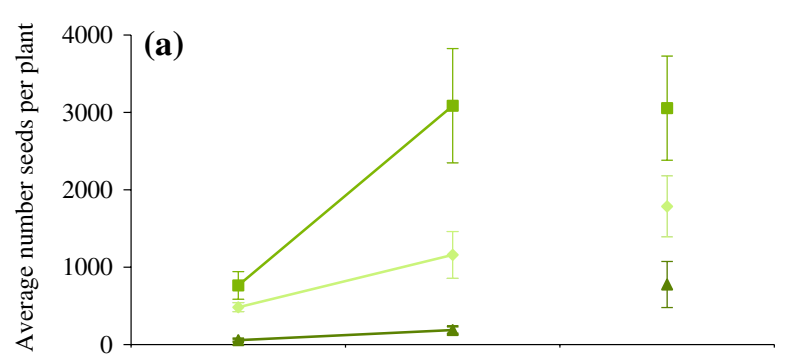

Sources

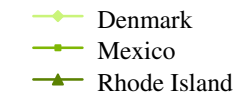

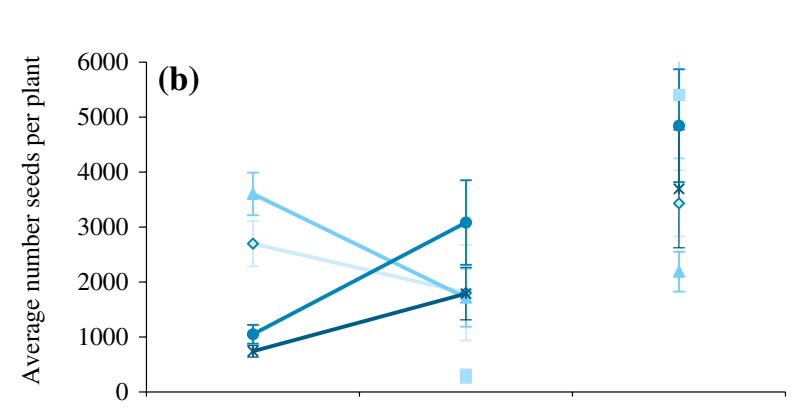
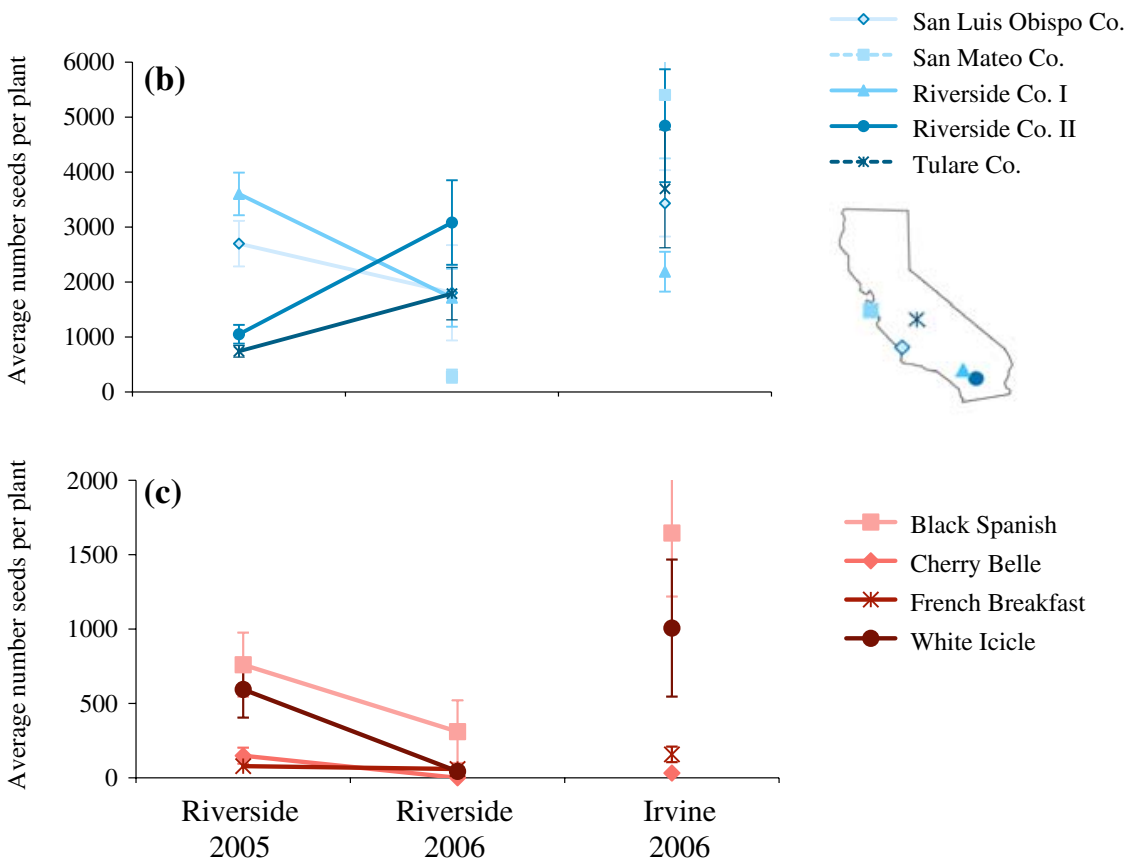

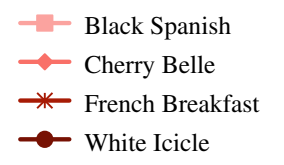

progenitors, and in Riverside in 2005 and Irvine in 2006, hybrid-derived California wild radish produced significantly more fruits per plant than either pure progenitor species. At Irvine in 2006, the hybridderived lineage also produced significantly more seeds. In all environments, California wild radish showed enhanced cumulative fitness. Since the introduction of Raphanus to California, the hybridderived lineage has greatly expanded its range throughout the state, replacing its exotic progenitors (Hegde et al. 2006). We suggest that the evolution of enhanced survival and reproduction in this lineage may be a mechanism for the success of the hybrid genotypes.

Our conclusions are based on field experiments where we supplied additional water and controlled herbivory. These 'altered' conditions are representative of at least a portion of environments that the progenitors originally colonized and that the hybrid- derived lineages have since spread to and continue to exploit successfully. Such environments include disturbed agricultural field margins and roadside ditches. We also argue as Baker (1974) did, that the ability of hybrid-derived California wild radish to take greater advantage of favorable conditions than either of its two progenitor parents is a hallmark of a successful weedy invader. We do not exclude the possibility that the differences in survival and rates of flowering favoring hybrid-derived California wild radish that we observed would be more pronounced had unaltered conditions prevailed.

The results we obtained using hybrids created naturally in situ are consistent with the results from studies using advanced generation artificial Raphanus hybrids grown in Michigan and California. Replicated populations of $F_{1}$ hybrids between $R$. raphanistrum and cultivated radish were allowed to evolve in old fields in northern Michigan for three 
Table 5 A comparison of total relative fitness between California wild radish and its progenitors in each site-year

\begin{tabular}{|c|c|c|c|c|c|c|c|}
\hline Site-year & Species & $N$ & $\begin{array}{l}\text { Proportion } \\
\text { survival to } \\
\text { reproduction }\end{array}$ & $\begin{array}{l}\text { Relative } \\
\text { survival to } \\
\text { reproduction }(\%)\end{array}$ & $\begin{array}{l}\text { Average } \\
\text { seed } \\
\text { number }\end{array}$ & $\begin{array}{l}\text { Relative } \\
\text { fecundity } \\
(\%)\end{array}$ & $\begin{array}{l}\text { Total } \\
\text { relative } \\
\text { fitness }(\%)\end{array}$ \\
\hline \multirow[t]{3}{*}{ Riverside 2005} & CA wild & 150 & 0.99 & 100 & 2,011 & 100 & 100 \\
\hline & R. raphanistrum & 200 & 0.92 & 93 & 501 & 25 & $23 * *$ \\
\hline & Cultivated & 200 & 0.68 & 69 & 428 & 21 & $15^{* *}$ \\
\hline \multirow[t]{3}{*}{ Riverside 2006} & CA wild & 53 & 0.98 & 100 & 1,803 & 100 & 100 \\
\hline & $R$. raphanistrum & 97 & 0.85 & 87 & 1,650 & 92 & $79 * *$ \\
\hline & Cultivated & 76 & 0.53 & 54 & 129 & 7.2 & $3.9 * *$ \\
\hline \multirow[t]{3}{*}{ Irvine 2006} & CA wild & 56 & 1 & 100 & 3,886 & 100 & 100 \\
\hline & R. raphanistrum & 98 & 1 & 100 & 1,892 & 49 & $49 * *$ \\
\hline & Cultivated & 79 & 0.87 & 87 & 777 & 20 & $17 * *$ \\
\hline
\end{tabular}

All relative rates are normalized to the highest value within a site-year. Relative fecundity is average for all individuals that survived to reproduce

** $P<0.001$ according to Fisher's exact test

seasons (three generations), and then a sample of the resulting seed was grown in common gardens in northern Michigan and Riverside, California (Campbell et al. 2006). Hybrid-derived lineages had reduced seed production compared to pure $R$. raphanistrum populations in Michigan but produced $250 \%$ more seed than $R$. raphanistrum in California. In the present experiment, we also found a significant reproductive advantage of hybrid-derived Raphanus in California and the advantage was somewhat environmentally dependent, as highlighted by the significant species $\times$ year interaction effect on average number of seeds produced per plant.

Artificial hybridization can contribute to our understanding of hybridization and invasion by recreating genotypes involved in relatively early post-hybridization scenarios and has the benefit of being able to control genetic history (e.g., Burke and Arnold 2001; Cummings et al. 2002; Lexer et al. 2003). In contrast, the natural hybrids in our experiment represent genotypes up to 150 generations away from the original interspecific hybridization event and have a vastly more complicated genetic history and present genetic constitution. These particular features of our study system have several implications. First, the relative fitness advantage of hybrid-derived Raphanus in certain environments is likely not only determined by its hybrid genetic makeup, but also by other evolutionary forces that have acted on the lineage in the last century and a half. While hybridization can create individuals with an immediate reproductive advantage over their progenitors due to heterosis, continued recombination in the hybrid lineages coupled with natural selection on the resulting diverse and unique hybrid genotypes could also result in the overall adaptive evolution. In Raphanus in California, hybridization may have been responsible for initial unique and beneficial combinations of traits and alleles, while natural selection acted in subsequent generations to adaptively 'finetune' its reproductive success. Such a situation is plausible given that California wild radish is phenotypically and genetically distinct from its progenitors (Hegde et al. 2006) and that, with its high genetic variability, obligately outcrossing breeding system and annual habit, California wild radish is also potentially highly capable of rapidly responding to natural selection.

The second, challenging part of working with natural hybrids derived over many decades is that their genetic history may be complicated with multiple possible parental source populations, multiple hybridization events and different patterns of inter-mating, backcrossing, and recombination. These complications may make experiments comparing progenitors and derivatives difficult to interpret. The essential question with regards our experiment is, have we chosen the most appropriate groups of plants to compare so that we can draw conclusions about hybridization and invasion of Raphanus in California. There is ample evidence that California wild radish is descended from $R$. raphanistrum and 
cultivated radish (Hegde et al. 2006; Panetsos and Baker 1967; Ridley et al. 2008), so that we can be sure we have at least included the correct progenitor species in the experiment. Unfortunately, more detailed information on the sources of introduction of the two progenitors is still lacking. Isozyme evidence confirms that the cultivars chosen here show high genetic similarity to some California wild radish individuals (Ellstrand and Marshall 1985), while recent cpDNA suggests that at least one introduction of $R$. raphanistrum came from northern Germany, making our inclusion of the nearby Danish $R$. raphanistrum population appropriate Ridley et al. (2008). Populations of pure $R$. raphanistrum and pure cultivated radish (or feral cultivated radish) from California might also have been a good basis of comparison, but as mentioned previously, all such pure populations are now extinct. Thus, we could not compare the traits of progenitor genotypes and derived genotypes with much specificity. Instead, we took the next best approach, measuring the fitness of a broad sampling of several cultivars, multiple potential sources of $R$. raphanistrum and several hybrid-derived populations from California. Even with the large differences between populations within species that we observed using this broad sampling approach, we were able to show a significantly enhanced fitness in the hybrid lineage in multiple environments.

Other field experiments that explicitly compare the fitness of hybrid invasive lineages derived in situ with that of progenitors are rare. In Germany, natural hybridization between an exotic and a native species of Rorippa has resulted in weedy hybrids with fitness equal to or lower than their parents, depending on environment (Bleeker and Matthies 2005). A study of Carpobrotus edulis, C. chilensis and their invasive natural hybrids in California revealed that hybrids consistently survive better and clonally outgrow their C. chilensis parent but not $C$. edulis and, again, that this result can vary across environments (Vila and D'Antonio 1998). These results and our own share the pattern that relative fitness varies with the specific environment. Collectively, they suggest the hybridization-invasion relationship may be idiosyncratic with the taxa and environments involved.

The proximate basis of high reproductive output of hybrid-derived lineages of Raphanus in California is not entirely clear and is not necessarily consistent between sites or through time. In Riverside 2005, it appears that $R$. raphanistrum-like early flowering and an intermediate size at flowering favored higher maternal reproductive success in California wild radish, while in Irvine 2006, an intermediate flowering date and large plant size at flowering correlated with higher fitness in California wild radish. This difference may be due to the later planting in 2005 as compared to 2006. In Michigan a third pattern emerges; selection tends to favor increased size at reproduction and advanced onset of reproduction in artificial, hybrid-derived lineages (Campbell and Snow 2007). Given that California wild radish is uniquely different from either of its progenitor parents by a complex suite of traits (Hegde et al. 2006) and that selection for trait values can vary significantly over space and time, it is perhaps not surprising that the reproductive success of California wild radish is not caused by a single trait or condition. Rather, it could be the diversity in life histories and vegetative-reproductive allocation strategies that can generally account for the hybrids' success.

Biologists have debated whether population-level phenotypic and genetic diversity confer increased colonization success in weeds (Baker 1974; Baker and Stebbins 1965) or increased invasiveness in introduced species (Ellstrand and Schierenbeck 2006). Studies of California wild radish reveal the presence of high genetic diversity in this lineage (Ellstrand and Marshall 1985; Hegde et al. 2006; Ridley et al. 2008). In this experiment, we also show that genotype $\times$ environment interactions characterize the performance of hybrid-derived populations, more so than populations of progenitor parent populations, evidence that hybrid populations maintain between population genotypic and phenotypic diversity. Population-level genetic diversity is a characteristic of a group, not of an individual, however, and as such is not an adaptive trait that can evolve by natural selection. It is a trait, however, that may be enhanced by gene flow (either intra- or interspecific gene flow) and could play a positive role in establishment and/or spread of an invasive species by providing the material upon which natural selection can act to create locally adapted populations, as Baker (1974) suggested. Our future studies of California wild radish will test for the presence of local adaptation and the role it may or may not play in the invasiveness of this lineage. 


\section{Conclusions}

Here, we present evidence for the evolution of enhanced survival and reproduction in a hybridderived invasive lineage. Our results imply, first of all, that using the precautionary principle and limiting the introduction of close congeners or species that have a close congener at the site of introduction could prevent the evolution of more invasive lineages. Second, evolutionary processes should be considered as a possible route to invasion, especially when available ecological explanations fail to fully explain the success of an introduced species. Unfortunately, the difficult reality is that evolving invasive species are moving targets. These populations shrink or grow, expand and adapt, and that means, if we value the communities that invasive species are irrevocably altering, we must understand and appreciate their evolutionary potential.

Acknowledgments We thank J. Clegg and J. Ross-Ibarra for collecting seed material, R. Tsao and the Ellstrand lab for lab and field support, and the personnel of the University of California, Riverside Agricultural Experiment Station and University of California South Coast Research and Extension Center for general field assistance. The research described in this paper has been funded in part by the United States Environmental Protection Agency (EPA) under a Science to Achieve Results (STAR) Graduate Fellowship to CER. EPA has not officially endorsed this publication and the views expressed herein may not reflect the views of the EPA. Research was also funded by NRI-CSREES-USDA grant 200335320-13559 to NCE.

Open Access This article is distributed under the terms of the Creative Commons Attribution Noncommercial License which permits any noncommercial use, distribution, and reproduction in any medium, provided the original author(s) and source are credited.

\section{References}

Ainouche ML, Baumel A, Salmon A, Yannic G (2004) Hybridization, polyploidy and speciation in Spartina (Poaceae). New Phytol 161:165-172. doi:10.1046/j.14698137.2003.00926.x

Arnold ML (1997) Natural hybridization and evolution. Oxford University Press, Oxford

Ayres DR, Strong DR, Baye P (2003) Spartina foliosa (Poaceae): a common species on the road to rarity? Madrono 50:209-213

Baker HG (1974) The evolution of weeds. Annu Rev Ecol Syst 5:1-24. doi:10.1146/annurev.es.05.110174.000245
Baker HG, Stebbins GL (1965) The genetics of colonizing species proceedings. Academic Press, New York

Barrett SCH, Colautti RI, Eckert CG (2008) Plant reproductive systems and evolution during biological invasion. Mol Ecol 17:373-383. doi:10.1111/j.1365-294X.2007.03503.x

Bartlett E, Novak SJ, Mack RN (2002) Genetic variation in Bromus tectorum (Poaceae): differentiation in the eastern United States. Am J Bot 89:602-612. doi:10.3732/ajb.89. 4.602

Bergelson J (1994) Changes in fecundity do not predict invasiveness: a model study of transgenic plants. Ecology 75:249-252. doi:10.2307/1939399

Bleeker W, Matthies A (2005) Hybrid zones between invasive Rorippa austriaca and native $R$. sylvestris (Brassicaceae) in Germany: ploidy levels and patterns of fitness in the field. Heredity 94:664-670. doi:10.1038/sj.hdy.6800687

Burke JM, Arnold ML (2001) Genetics and the fitness of hybrids. Annu Rev Genet 35:31-52. doi:10.1146/annurev. genet.35.102401.085719

Campbell LG, Snow AA (2007) Competition alters life history and increases the relative fecundity of crop-wild radish hybrids (Raphanus spp.). New Phytologist 173: 648-660

Campbell LG, Snow AA, Ridley CE (2006) Weed evolution after crop gene introgression: greater survival and fecundity of hybrids in a new environment. Ecol Lett 9:11981209. doi:10.1111/j.1461-0248.2006.00974.x

Colautti RI, Grigorovich IA, MacIsaac HJ (2006) Propagule pressure: a null model for biological invasions. Biol Invasions 8:1023-1037. doi:10.1007/s10530-005-3735-y

Conner JK (1997) Floral evolution in wild radish: the roles of pollinators, natural selection, and genetic correlations among traits. Int J Plant Sci 158:S108-S120. doi:10.1086/ 297511

Cox GW (2004) Alien species and evolution: the evolutionary ecology of exotic plants, animals, microbes and interacting native species. Island Press, Washington, p 400

Cummings CL, Alexander HM, Allison AS, Rieseberg LH, Kim MJ, Culley TM (2002) Fecundity selection in a sunflower crop-wild study: can ecological data predict crop allele changes? Ecol Appl 12:1661-1671

Devlin B, Ellstrand NC (1990) Male and female fertility variation in wild radish, a hermaphrodite. Am Nat 136:87107. doi: $10.1086 / 285083$

DiTomaso JM, Healy EA (2006) Weeds of California and other western states. University of California Division of Agriculture and Natural Resources, Oakland

Dlugosch KM, Parker IM (2008) Founding events in species invasions: genetic variation, adaptive evolution, and the role of multiple introductions. Mol Ecol 17:431-449. doi: 10.1111/j.1365-294X.2007.03538.x

Durka W, Bossdorf O, Prati D, Auge H (2005) Molecular evidence for multiple introductions of garlic mustard (Alliaria petiolata, Brassicaceae) to North America. Mol Ecol 14:1697-1706. doi:10.1111/j.1365-294X.2005.02521.x

Elam DR, Ridley CE, Goodell K, Ellstrandt NC (2007) Population size and relatedness affect fitness of a selfincompatible invasive plant. Proc Natl Acad Sci USA 104:549-552. doi:10.1073/pnas.0607306104

Ellstrand NC, Marshall DL (1985) The impact of domestication of distribution of allozyme variation within and 
among cultivars of radish Raphanus sativus. Theor Appl Genet 69:393-398. doi:10.1007/BF00570908

Ellstrand NC, Schierenbeck KA (2006) Hybridization as a stimulus for the evolution of invasiveness in plants? Euphytica 148:35-46. doi:10.1007/s10681-006-5939-3

Ellstrand NC, Devlin B, Marshall DL (1989) Gene flow by pollen into small populations-data from experimental and natural stands of wild radish. Proc Natl Acad Sci USA 86:9044-9047. doi:10.1073/pnas.86.22.9044

Facon B, Jarne P, Pointier JP, David P (2005) Hybridization and invasiveness in the freshwater snail Melanoides $t u$ berculata: hybrid vigour is more important than increase in genetic variance. J Evol Biol 18:524-535. doi:10.1111/ j.1420-9101.2005.00887.x

Genton BJ, Shykoff JA, Giraud T (2005) High genetic diversity in French invasive populations of common ragweed, Ambrosia artemisiifolia, as a result of multiple sources of introduction. Mol Ecol 14:4275-4285

Hayes KR, Barry SC (2008) Are there any consistent predictors of invasion success? Biol Invasions 10:483-506. doi: 10.1007/s10530-007-9146-5

Hegde SG, Nason JD, Clegg JM, Ellstrand NC (2006) The evolution of California's wild radish has resulted in the extinction of its progenitors. Evol Int J Org Evol 60:11871197

Holm L, Doll J, Holm E, Pancho J, Herberger J (1997) World weeds: natural histories and distributions. Wiley, New York

Irwin RE, Strauss SY, Storz S, Emerson A, Guibert G (2003) The role of herbivores in the maintenance of a flower color polymorphism in wild radish. Ecology 84:17331743. doi:10.1890/0012-9658(2003)084[1733:TROHIT] 2.0.CO;2

Keller SR, Taylor DR (2008) History, chance and adaptation during biological invasion: separating stochastic phenotypic evolution from response to selection. Ecol Lett 11:852-866. doi:10.1111/j.1461-0248.2008.01188.x

Lambrinos JG (2004) How interactions between ecology and evolution influence contemporary invasion dynamics. Ecology 85:2061-2070. doi:10.1890/03-8013

Lavergne S, Molofsky J (2007) Increased genetic variation and evolutionary potential drive the success of an invasive grass. Proc Natl Acad Sci USA 104:3883-3888. doi: 10.1073/pnas.0607324104

Lee CE (2002) Evolutionary genetics of invasive species. Trends Ecol Evol 17:386-391. doi:10.1016/S0169-5347 (02)02554-5

Lexer C, Randell RA, Rieseberg LH (2003) Experimental hybridization as a tool for studying selection in the wild. Ecology 84:1688-1699. doi:10.1890/0012-9658(2003)084 [1688:EHAATF]2.0.CO;2

Lockwood JL, Cassey P, Blackburn T (2005) The role of propagule pressure in explaining species invasions. Trends Ecol Evol 20:223-228. doi:10.1016/j.tree.2005.02. 004

Maron JL, Vila M, Bommarco R, Elmendorf S, Beardsley P (2004) Rapid evolution of an invasive plant. Ecol Monogr 74:261-280. doi:10.1890/03-4027

Marrs RA, Sforza R, Hufbauer RA (2008) When invasion increases population genetic structure: a study with
Centaurea diffusa. Biol Invasions 10:561-572. doi: 10.1007/s10530-007-9153-6

Marshall DL, Diggle PK (2001) Mechanisms of differential pollen donor performance in wild radish, Raphanus sativus (Brassicaceae). Am J Bot 88:242-257. doi:10.2307/ 2657015

Matkin OA, Chandler PA (1967) The U.C.-type soil mixes. In: Baker KF (ed) The U.C. system for producing healthy container-grown plants, Division of Agricultural Sciences, Agricultural Experiment Station, Extension Service. University of California, Berkeley, pp 68-85

Mazer SJ, Schick CT (1991) Constancy of population parameters for life-history and floral traits in Raphanus sativus $\mathrm{L}$. 1 . Norms of reaction and the nature of genotype by environment interactions. Heredity 67:143-156. doi:10.1038/ hdy. 1991.74

Nason JD, Ellstrand NC (1995) Lifetime estimates of biparental inbreeding depression in the self-incompatible annual plant Raphanus sativus. Evol Int J Org Evol 49:306-316. doi:10.2307/2410341

Novak SJ, Mack RN (2001) Tracing plant introduction and spread: genetic evidence from Bromus tectorum (cheatgrass). Bioscience 51:114-122. doi:10.1641/0006-3568 (2001)051[0114:TPIASG]2.0.CO;2

Panetsos CA, Baker HG (1967) The origin of variation in "wild" Raphanus sativus (Cruciferae) in California. Genetica 38:243-274. doi:10.1007/BF01507462

Parker IM, Rodriguez J, Loik ME (2003) An evolutionary approach to understanding the biology of invasions: local adaptation and general-purpose genotypes in the weed Verbascum thapsus. Conserv Biol 17:59-72. doi:10.1046/ j.1523-1739.2003.02019.x

Rice WR (1990) A consensus combined $P$ value test and the family-wide significance of component tests. Biometrics 46:303-308. doi: $10.2307 / 2531435$

Ridley CE (2008) Hybridization and the evolution of invasiveness in the California wild radish (Raphanus sativus), Botany and Plant Sciences. University of California Riverside, Riverside, p 138

Ridley CE, Kim SC, Ellstrand NC (2008) Bi-directional history of hybridization in California wild radish Raphanus sativus (Brassicaceae) as revealed by chloroplast DNA. Am J Bot 95:1437-1442

Rieseberg LH, Archer MA, Wayne RK (1999) Transgressive segregation, adaptation and speciation. Heredity 83:363372. doi: $10.1038 /$ sj.hdy. 6886170

Robbins WW (1940) Alien plants growing without cultivation in California. College of Agriculture. University of California, Berkeley, p 128

Sakai AK, Allendorf FW, Holt JS, Lodge DM, Molofsky J, With KA, Baughman S, Cabin RJ, Cohen JE, Ellstrand NC, McCauley DE, O'Neil P, Parker IM, Thompson JN, Weller SG (2001) The population biology of invasive species. Annu Rev Ecol Syst 32:305-332. doi:10.1146/ annurev.ecolsys.32.081501.114037

SAS Institute Inc (2003) SAS 9.1. Cary, North Carolina SAS Institute Inc (2007) JMP 7.0. Cary, North Carolina

Snow AA, Campbell LG (2005) Can feral radishes become weeds? In: Gressel JB (ed) Crop ferality and volunteerism. CRC Press, Boca Raton, pp 175-192 
Snow AA, Uthus KL, Culley TM (2001) Fitness of hybrids between weedy and cultivated radish: implications for weed evolution. Ecol Appl 11:934-943. doi:10.1890/ 1051-0761(2001)011[0934:FOHBWA]2.0.CO;2

Sokal RR, Rohlf FJ (1995) Biometry. W. H. Freeman and Company, New York

Stace CA (1975) Hybridization and the flora of the British Isles. Academic Press, London, p 626

Stanton M, Young HJ, Ellstrand NC, Clegg JM (1991) Consequences of floral variation for male and female reproduction in experimental populations of wild radish,
Raphanus sativus L. Evol Int J Org Evol 45:268-280. doi: 10.2307/2409662

Valladares F, Sanchez-Gomez D, Zavala MA (2006) Quantitative estimation of phenotypic plasticity: bridging the gap between the evolutionary concept and its ecological applications. J Ecol 94:1103-1116. doi:10.1111/j.13652745.2006.01176.x

Vila M, D’Antonio CM (1998) Hybrid vigor for clonal growth in Carpobrotus (Aizoaceae) in coastal California. Ecol Appl 8:1196-1205 